\title{
ENTREVISTA A STEPHEN KRASHEN
}

Interview with Stephen Krashen, by Victoria Rodrigo and Juan de Dios Villanueva

We have the honor and pleasure to talk with Dr. Stephen Krashen, a leading theorist in the field of reading, bilingual education, and secondlanguage acquisition, and emeritus professor at the University of Southern California in Los Angeles. Dr. Krashen has written more than 20 books and 460 articles on these topics. We talked to him about the role of reading in the acquisition of our first and second language and what can we do to promote reading. We hope you enjoy this interview.

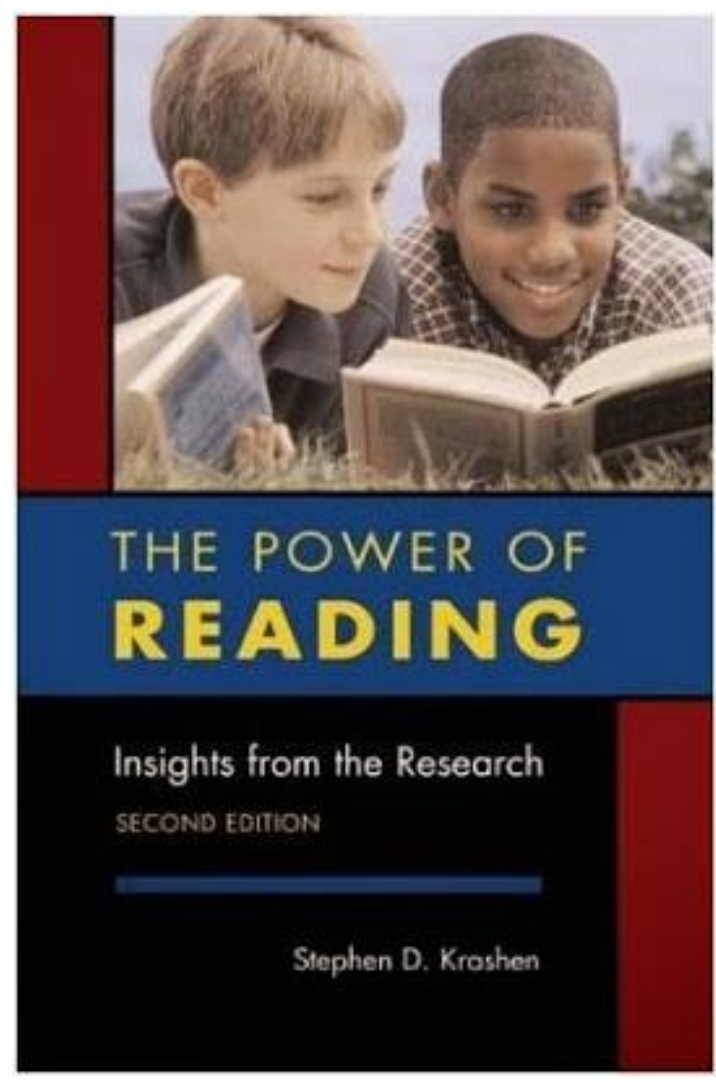

Entrevista a Stephen Krashen, por Victoria Rodrigo y Juan de Dios Villanueva.

Es un honor y un placer hablar con del Dr. Stephen Krashen, profesor emérito de la Universidad del Sur de California en Los Ángeles y destacado teórico en el campo de la lectura, educación bilingüe y adquisición de segundas lenguas. Dr. Krashen ha escrito más de 20 libros y 460 artículos en estos temas. Hemos hablado con él sobre el papel de la lectura en la adquisición de la primera y segunda lengua y sobre qué podemos hacer para promover el gusto por la lectura. Esperamos que disfruten de la entrevista.

\section{What is the role of reading in the acquisition of a native or a foreign language? Is it true that we can learn a language by reading? How come?}

There is one kind of reading is extremely helpful for acquiring and developing both first and second languages: Reading that we do because we want to, sometimes called "selfselected reading," sometimes called "pleasure reading," and sometimes called "recreational reading." For both first and second language development, study after study has shown that pleasure reading is the major source of our reading ability and our ability to write using a respectable writing style. It is also the major source of our vocabulary knowledge and our ability to use and understand complicated grammatical rules. The "power of reading" is one of the best-established and consistent findings in all of educational research. 
Of course, to acquire a second language, reading alone is not enough. Aural input is also necessary. But reading can make a very powerful contribution. In fact, reading may be the only way we reach the highest levels of language proficiency.

\section{1. ¿Qué papel juega la lectura en la adquisición de la primera lengua o de una lengua extranjera? ¿Es cierto que podemos aprender una lengua a través de la lectura? ¿Cómo es posible?}

Hay un solo tipo de lectura que resulta altamente útil en la adquisición y desarrollo tanto de una primera lengua como de una segunda lengua: la lectura que hacemos porque queremos hacerla, a veces denominada "lectura auto-seleccionada", a veces llamada "lectura por placer" y, otras veces, "lectura recreacional". En el desarrollo tanto de la primera como de una segunda lengua, la investigación ha mostrado una y otra vez que la lectura por placer es la principal fuente de nuestra capacidad lectora y de nuestra capacidad de escribir con un nivel respetable de redacción. Es también la principal fuente de conocimiento de vocabulario y de la capacidad de usar y entender reglas gramaticales complejas. El "poder de la lectura" es uno de los hallazgos más ampliamente establecidos y consistentes en toda la investigación en educación.

Por supuesto, para adquirir otra lengua, la lectura por sí sola no es suficiente. El input auditivo también es necesario. Sin embargo, la lectura puede constituirse en una poderosa ayuda. De hecho, es posible que sea la única manera de alcanzar los niveles más altos de dominio de una lengua.

2. So, if reading is so important, what is the best way to learn how to read in a foreign language? What about for a bilingual child?

What effective methods for learning to read have in common is that they provide the reader with lots of comprehensible and interesting things to read. For young children and beginning second and foreign language students, true "recreational reading" won't be possible. But we can help less advanced readers move to independent reading by reading aloud to them and telling them lots of stories. and with the use of very easy readers (such as graded readers, see discussion below).

There is a wonderful method that was popular in the 1960's that is not used much anymore, possibly because publishers can't make any money from it: Language Experience. The student dictates the story to the teacher. The teacher retypes it correctly, and with the permission of the "author" prints out copies for all students. Students are very interested in reading their own stories or so are their classmates. A cheap (free!), easy way to build a classroom library rapidly!

Bilingual children learn to read quickly when they learn to read in their stronger language. It is easier to learn to read in a language that one understands, and once you can read in one language, the reading ability then transfers rapidly to the second language.

2. Entonces, si la lectura es tan importante, ¿cuál es la mejor manera de aprender a leer en una lengua extranjera? ¿Qué ocurre en el caso de los niños bilingües? 
Lo que tienen en común los métodos eficaces en el desarrollo de la lectura es que le brindan al lector gran cantidad de cosas que puede entender y que le resultan interesantes de leer. Para los más pequeños y los aprendices iniciales de lengua segunda o extranjera, la lectura verdaderamente recreacional no será posible, pero sí podemos ayudar a los lectores menos avanzados a convertirse en lectores independientes leyéndoles libros y contándoles muchos cuentos, y a través del uso de lecturas muy simples (tales como las lecturas graduadas_-como digo más adelante).

Hay un excelente método que se popularizó en los años sesenta y que ya no se usa mucho, posiblemente porque las editoriales ya no pueden ganar dinero con él: Language Experience. El estudiante le dicta una historia al profesor. El profesor le da su forma final y, con el permiso del 'autor', hace copias para todos los alumnos. Estos se interesan mucho en leer sus propias historias y los compañeros también. Es una manera barata ( $¡ y$ gratis!) de construir muy rápido una biblioteca en el aula.

Los niños bilingües aprenden a leer muy rápido cuando aprenden a leer en la lengua que dominan más. Es más fácil aprender a leer en la lengua que uno entiende. Una vez que lees en una lengua, la capacidad lectora se transfiere rápidamente a la otra lengua.

\section{What is the benefit of reading aloud to children? Why is it so important?}

Nearly all children like being read to and it is highly beneficial. Children who are read to regularly, either at school or at home, outperform children not read to regularly on aural tests of vocabulary and grammar, which helps them understand texts when they read. They also get enthusiastic about reading.

Much of the enthusiasm about reading aloud today is because of a very important book, The Read-Aloud Handbook, by Jim Trelease. This engaging book has been very popular among parents in North America and has sold millions of copies.

\section{3. ¿Cuál es el beneficio de leerles cuentos a los niños? ¿Por qué es tan importante?}

A casi todos los niños les gusta que les lean cuentos, y es muy beneficioso. Los niños a los que se les lee con regularidad, ya sea en la escuela o en casa, comparados con los niños a los que no se les lee regularmente, obtienen mejores resultados en exámenes auditivos de vocabulario y gramática, lo que los ayuda a entender textos cuando leen. También demuestran mayor entusiasmo por la lectura.

El gran entusiasmo hoy en día por la lectura se debe a una publicación muy importante, The Read-Aloud Handbook, de Jim Trelease. Este interesante libro se ha popularizado entre los padres y madres de Estados Unidos y ha vendido millones de copias.

\section{What is being done in the States to promote reading for pleasure among children?}

Not much in the last few years!!! There is a great deal of child poverty in the US: $24 \%$ of American children now live in poverty, which means, among other things, little access to books. It is a very strange time: More and more research is emerging showing that 
library quality is relating to reading ability. Children who attend schools with better school libraries read better.

Our research using the PIRLS test is one of the studies that shows this. We found that the school library was a very strong predictor of PISA reading scores across 40 countries, independent of the effect of poverty [1].

But at the same time, funding for public and school libraries in the US is being cut. This is a terrible thing: The only place children of poverty can get books is in libraries. Unfortunately, a great deal of money is being spent on testing: We are weighing the animal instead of feeding it.

\section{4. ¿Qué se hace en Estados Unidos para promover la lectura por placer entre los niños?}

¡No mucho en los últimos años! Hay una gran cantidad de niños en la pobreza en Estados Unidos: un $24 \%$ de los niños estadounidenses vive hoy en la pobreza, lo que significa, entre otras cosas, que hay poco acceso a los libros. La situación actual es muy extraña: hay cada vez más y más investigación que demuestra que hay una relación entre la calidad de las bibliotecas y capacidad lectora. Los niños que asisten a escuelas que tienen mejores bibliotecas leen mejor.

Nuestra propia investigación con los tests PIRLS es uno de los estudios que lo muestra. Determinamos que la biblioteca de la escuela era un gran predictor de los índices PISA de lectura entre 40 países, independientemente del efecto de la pobreza [1].

Pero, a la vez, se eliminan los fondos para bibliotecas públicas y en las escuelas de EEUU. Esto es terrible: el único lugar en que los niños pobres pueden obtener libros es en las bibliotecas. Lamentablemente, gran parte del dinero se gasta en evaluar. Estamos pesando al animal en vez de alimentarlo.

5. In the States there is something call Sustained Silent Reading? What is it? Is it successful?

In sustained silent reading (SSR), students do self-selected reading for short periods of time each time, usually about ten or 15 minutes each day. There is little or no "accountability" - no book reports and no tests on what they read. During SSR time, the teacher also does recreational reading - it's a nice break in the day for the teacher.

SSR clearly works, as long as the program continues for a sufficient length of time (more than just a few weeks), and there is a supply of genuinely interesting books. Students in classes using SSR typically do better than students who do not have SSR time on tests of vocabulary and reading comprehension, and they read more on their own. In one study, children who participated in a sustained silent reading program reported reading more than comparison students six years after the program ended [2].

\section{En Estados Unidos se implementa el llamado Sustained Silent Reading (lectura} silenciosa sostenida)? ¿Qué es? ¿Ha tenido éxito? 
En la lectura silenciosa sostenida (SSR, por sus siglas en inglés), los alumnos hacen lecturas que seleccionan ellos mismos, por períodos breves, generalmente por unos 10 a 15 minutos por día. No hay que rendir cuentas de lo leído haciendo resúmenes de lectura ni pruebas. Durante estas actividades, el maestro también hace lectura recreacional. Es una pausa agradable de la jornada para el maestro.

La SSR, sin duda, funciona si el programa de lectura se realiza por tiempo suficiente (más allá de un par de semanas) y si se dispone de una buena cantidad de libros verdaderamente interesantes. En comparación con otros alumnos, los de las clases en las que se hace SSR típicamente obtienen mejores resultados en pruebas de vocabulario y de comprensión lectora, y leen más por su cuenta. En un estudio, los niños que participaron en un programa de lectura silenciosa sostenida declararon que leían más que otros estudiantes seis años después de terminado el programa [2].

6. Let's talk about a foreign language. What do you think about the use of graded readers in the teaching of a foreign language?

Graded readers are short novels (and sometimes nonfiction) written especially for seecond language acquirers. Reading graded readers can build the vocabulary and grammar needed to read "authentic" books and are written at a variety of difficulty levels. Several case histories show that language students can make remarkable progress reading graded readers, and little else [3].

\section{Pasemos a hablar de una lengua extranjera ¿Qué le parece el uso de lecturas graduadas en la enseñanza de un idioma extranjero?}

Las lecturas graduadas son novelas cortas (a veces no de ficción) escritas especialmente para aprendices de una segunda lengua. Leer lecturas graduadas puede desarrollar el vocabulario y la gramática necesaria para leer libros "auténticos" y se producen para una variedad de niveles. Varios estudios de caso muestran que los aprendices de una lengua pueden alcanzar un gran desarrollo leyendo lecturas graduadas [3].

\section{What about people who say they don't like to read?}

There aren't too many people who can read and don't like to read. Very often, someone who says that he or she "doesn't like to read" thinks that reading only counts when it is a classic, something boring and difficult. They don't respect the books and magazines that they read.

When we see real cases of "reluctant readers" it is usually because they haven't yet found what interests them, and this is because they haven't been exposed to lots of different kinds of reading. This is happening more often as books become more expensive and libraries are losing funding.

\section{7. ¿Y qué pasa con aquellos que dicen que no les gusta leer?}


No hay mucha gente que sepa leer y que no le guste hacerlo. Con frecuencia, alguien que diga que "no le gusta leer" piensa que la única lectura que cuenta es la de una obra clásica, algo aburrido y difícil. No valoran ellos los libros y revistas que puedan leer.

Cuando nos fijamos en casos reales de 'lectores reticentes', resulta que se debe a que no han encontrado todavía lo que les interesa, lo cual se debe a que no han tenido acceso a múltiples tipos de lectura. Esto ocurre con mayor frecuencia en la medida en que los libros son más caros y las bibliotecas pierden financiación.

8. If you were a language program administrator and finally obtain an ideal amount of money on your budget, what would you use it for? Computers and a brand new language lab or a new library? Why?

I vote for the library. I have done two reviews of computer-based language teaching programs and I found that the results do not live up to the claims made [4]. I have also found no research supporting commercial software designed to improve accent [5].

8. Si fuera usted es el responsable académico de un programa de lengua y por fin consigue una cantidad de dinero extra en su presupuesto, ¿a qué lo destinaría? ¿Ordenadores y nuevo laboratorio de lenguas o una nueva biblioteca? ¿Por qué?

Voto por la biblioteca. He hecho dos revisiones de programas de lengua con instrucción por ordenador y he concluido que los resultados no cumplen las expectativas iniciales [4].

Tampoco he encontrado ninguna investigación que apoye el uso de software comercial en la corrección del acento [5].

9 Nowadays the technology has invaded our lives even in the field of reading. Now we don't need to go to libraries, bookstores to get a book; technology will provide it. What do you think is the role of technology in learning and loving to read? Do you think that iPad, Kindle and the like will eventually replace the 'real book'?

Yes, I think that full "kindlization" will happen, but not as soon as people think it will. The big problem with e-book and e-book readers is their expense. Studies by the Pew organization show that so far in the US, e-book reader owners are generally middle-class or wealthy. When e-books and e-book readers become much less expensive, and when users can freely share e-books, then we will see a large increase in e-book reading. Thus far, e-books have made only a slight impact on reading. There are still few e-books in school libraries in the US, and e-book sales have negatively influenced the sale of paperbacks, but not all that much. I summarized some of this research [6].

9. Hoy en día la tecnología ha invadido nuestras vidas incluso en el campo de la lectura. Ahora no es necesario ir a la biblioteca, a la librería para conseguir un libro. Lo provee la tecnología. ¿Cuál cree usted que es el papel de la tecnología en el aprendizaje y en la 
apreciación de la lectura? ¿Cree usted que el iPad, el Kindle y similares finalmente reemplazará al 'libro tradicional'?

Sí, creo que la completa "Kindlización" va a ocurrir, pero no tan pronto como creen algunos. El gran problema de los libros y lecturas electrónicas es su coste. Estudios de la Organización Pew muestran que, hasta ahora en Estados Unidos, los propietarios de lectores electrónicos son por lo general gente de la clase media o de grupos acomodados. Cuando los libros y lectores electrónicos bajen mucho más de precio y cuando sus lectores puedan compartir sus lecturas, entonces veremos un gran incremento de la lectura electrónica. Hasta ahora, los libros electrónicos solo han tenido un impacto leve en los hábitos de lectura. Hay pocos libros electrónicos en las bibliotecas de las escuelas de Estados Unidos y su venta ha afectado negativamente la de libros en su formato más barato-libro de bolsillo-, aunque el efecto ha sido leve. Alguna de la investigación sobre este tema ya la he presentado [6].

Victoria Rodrigo y Juan de Dios Villanueva

[1] Krashen, S., Lee, S.Y. and McQuillan, J. 2012. Is the library important? Multivariate studies at the national and international level. Journal of Language and Literacy Education, 8(1): 26-36.

[2] (Greaney, V., and M. Clarke, M. 1973. A longitudinal study of the effects of two reading methods on leisure-time reading habits. In Reading: What of the future? ed. D. Moyle. London: United Kingdom Reading Association. Pp. 107-114.)

[3] (e.g Mason, B. and Krashen, S. 1997. Extensive reading in English as a foreign language. System 25: 91-102.)

[4] Krashen, S. 2013. Rosetta Stone: Does not provide compelling input, research reports at best suggestive, conflicting reports on users' attitudes. International Journal of Foreign Language Teaching, 8:1.

Krashen, S. 2014. Does Duolingo "trump" university-level language learning? International Journal of Foreign Language Teaching 9(1):13-15.

[5] Krashen, S. 2013. The effect of direct instruction on pronunciation: Only evident when conditions for Monitor use are met? GiST: Education and Learning Research Journal 7: 271-275.

[6] Krashen, S. 2011. Kindelization: Are books obsolete? Journal of the California School Library Association, CSLA 3(2):10-11 